\title{
BUILDING A SECURE FENCE AND A WELL-FUNCTIONING AMBULANCE: REFORMING NEW ZEALAND'S NATURAL DISASTER INSURANCE SCHEME
}

\author{
Hanna Malloch*
}

This article proposes reform to New Zealand's natural disaster insurance scheme in anticipation of The New Zealand Treasury's (Treasury) 2021 review of the Earthquake Commission Act 1993. The Canterbury Earthquake Sequence of 2010-2011 revealed many shortcomings in New Zealand's dualinsurance model, outlined in the March 2020 Public Inquiry into the Earthquake Commission. Recent changes in the private insurance market have aggravated these problems, notably, increasing premiums and a move to sum-insured policies. This article explores the lesser known background to the unique EQC system and examines the fundamental reasons for this public system. It aims to establish the most effective natural disaster insurance scheme for New Zealand, holding that retaining the dual-model approach is preferable. However, fresh reforms are necessary. Five reforms are proposed: ensuring the scheme's universality; increasing the EQC cap; implementing differentiated pricing; incorporating incentives for mitigation; including a purpose statement within the Act. Implementing these reforms will best ensure the scheme meets the objective of allowing homeowners to build their secure fence at the top of the cliff, while still ensuring there is a well-functioning ambulance at the bottom.

\section{INTRODUCTION}

Natural disasters are an inescapable fact of life for those living in Aotearoa New Zealand. Because of this, an effective natural disaster insurance scheme is of utmost importance. Currently, New Zealand's residential natural disaster insurance is operated through a unique dual-insurance model

* Submitted for LLB (Honours) Degree, Victoria University of Wellington 2020. I would like to express my great appreciation to my supervisor, Dr Bevan Marten, for his support and guidance with this research article. I would also like to pay my respects to the victims of the Canterbury earthquakes, their whānau, and acknowledge those impacted by insurance battles, including those fighting for justice today. 
between the Earthquake Commission (EQC), the Government insurer and private insurance companies. This EQC scheme faced immense scrutiny following the Canterbury earthquake sequence of 2010-2011, ${ }^{1}$ resulting in a Public Inquiry into the operation of the Earthquake Commission. Released in March 2020, the Public Inquiry's report will be followed by a comprehensive New Zealand Treasury (Treasury) review of the Earthquake Commission Act 1993 (the Act) in 2021. ${ }^{2}$

In anticipation of Treasury's review, this article seeks to determine the most effective model for New Zealanders. Looking at post-Canterbury failures, there is much to be done in creating a better model for the future. As the Māori proverb goes, He aha te mea nui o te ao? What is the most important thing in the world? He tangata, he tangata, he tangata. It is the people, it is the people, it is the people. Accordingly, New Zealand homeowners need to be at the forefront of New Zealand's natural disaster insurance scheme. New Zealanders both deserve and expect an effective and efficient scheme that operates with their best interests in mind. The current system fails to meet this standard. In light of identified deficiencies, this article proposes to retain the bones of the current scheme but implement five new reforms: ensuring the scheme's universality; increasing the EQC cap; implementing differentiated pricing; including incentives for mitigation; and adding a purpose statement to the Act. Doing so will ensure that New Zealand homeowners are best protected following a natural disaster.

\section{TRIGGERS FOR REFORM}

Following any natural disaster, insurance is consistently identified as a particularly vexed issue. ${ }^{3}$ This notion was reflected after the Canterbury earthquake sequence, the most damaging natural disasters experienced in recent New Zealand history. The Canterbury sequence began with a magnitude 7.1 earthquake at $4.35 \mathrm{am}$ on 4 September 2010 which claimed one life and seriously injured two others. At magnitude 6.3, the second and most devastating earthquake struck at $12.51 \mathrm{pm}$ on 22 February 2011 presenting unprecedented seismic complexity. ${ }^{4} 185$ people lost their lives, thousands were injured and widespread damage to land and buildings ensued. Other major earthquakes occurred on 13 June 2011 - two earthquakes measuring magnitudes 5.7 and 6.0 - and 23 December 2011 - two earthquakes measuring magnitudes 5.8 and 5.9. Overall, the Canterbury earthquake sequence comprised four major events, 11 other "damage-causing events" for the purpose of insurance claims, and almost 18,000 aftershocks. ${ }^{5}$ Over 90 per cent of all Christchurch dwellings

1 Public Inquiry into the Earthquake Commission Report of the Public Inquiry into the Earthquake Commission (March 2020) at 8.

2 Earthquake Commission Statement of Performance Expectations 2020-2021 (2020) at 8.

3 Jeremy Finn and Elizabeth Toomey Legal Response to Natural Disasters (Thomson Reuters, New Zealand, 2015) at 196.

4 Public Inquiry into the Earthquake Commission, above n 1, at 43.

5 At 43. 
sustained damage, ${ }^{6}$ and the resulting liquefaction was the biggest urban liquefaction event in the modern world. ${ }^{7}$ Various natural disasters succeeded the Canterbury earthquakes. Most notably, the November 2016 Kaikōura earthquake which generated 40,000 EQC claims. ${ }^{8}$

Before September 2010, EQC had dealt with a maximum of 6,000 claims following a natural disaster; a number dwarfed by the 460,000 claims following the Canterbury earthquakes. ${ }^{9}$ Consisting of 760,000 sub-claims relating to homes, contents, and land, the sheer quantity of claims closely matched those arising from Hurricane Katrina. ${ }^{10}$ By and large, EQC claimants express dissatisfaction with EQC's operational practices and the outcomes of their claims. Common complaints include poor communication, inadequate record-keeping, poor treatment by staff, and an unsatisfactory complaints/dispute process. ${ }^{11}$ EQC undoubtedly faced an overwhelming task. However, this was made worse by its unpreparedness, inadequate internal systems, an absence of clear prior direction and added responsibilities, such as management of the Christchurch Home Repair Programme. ${ }^{12}$ The public bore the burden of these shortcomings resulting in unacceptable stress, distress and delays in people's personal recovery and home repairs. ${ }^{13}$ To emphasise, as at March 2020, 2,358 residential property claims remained unsettled. ${ }^{14}$ As the chair of the Public Inquiry, Dame Silvia Cartwright stated the stressful consequences of the interactions with EQC, private insurers and government departments have been a "palpable re-traumatisation of affected people". ${ }^{15}$ New Zealanders deserve better following a natural disaster.

6 Sarah Beaven The Residential Advisory Service: Collaborative Governance After a New Zealand Disaster (University of Canterbury Research Report, December 2017) at 8.

7 Public Inquiry into the Earthquake Commission, above n 1, at 43.

8 At 46

9 At 44 .

10 Finn and Toomey, above $\mathrm{n}$ 3, at 196.

11 Public Inquiry into the Earthquake Commission What We Heard: Summary of feedback from the Inquiry's public engagement (March 2020) at 7.

12 Public Inquiry into the Earthquake Commission, above n 1, at 11.

13 At 8 .

14 Cabinet Paper "Government Response to the Public Inquiry into the Earthquake Commission Information Release" (24 June 2020) CAB DEV-20-SUB-0116 at 11.

15 Public Inquiry into the Earthquake Commission, above n 1, at 17. 


\section{NEW ZEALAND'S NATURAL DISASTER INSURANCE SCHEME}

\section{A The Current Scheme}

Before 1944, natural disaster insurance was a voluntary measure available only from private sector insurance companies. In practice, the bulk of the population chose not to take out a policy. ${ }^{16}$ In response, the Earthquake and War Damage Commission (EWDC) was established in $1945 .{ }^{17}$ Firmly embedded in egalitarianism, ${ }^{18}$ the scheme favoured a collective, public approach to natural disasters holding that the "whole loss is deemed to be a national loss". ${ }^{19}$ As a monopoly insurer, the EWDC covered every physical asset in New Zealand against earthquake, war, landslip and disaster damage. ${ }^{20}$

This scheme soon became incompatible with the emerging neoliberal political environment which prioritised individualism. ${ }^{21}$ Further, the workings of the scheme itself were shaky. As many property owners remained uninsured, there was uncertainty around the extent of governmental assistance for these homeowners. If the Government intended to be generous in this assistance, it would penalise the prudent who took out their own insurance. If not, it would be viewed as irresponsible in allowing a system which left so many unprotected. ${ }^{22}$ In this sense, the scheme was described as providing a "shaky fence at the top of the cliff and a broken-down ambulance at the bottom". ${ }^{23}$ Instead, a "secure fence at the top and a well-functioning ambulance at the bottom" was necessary. ${ }^{24}$ In response, the 1993 reforms abandoned the collective national response to non-residential insurance in favour of a free-market system. ${ }^{25}$ To reduce the Government's exposure to losses and allow commercial interests

16 New Zealand Government A Review of Earthquake Insurance: Public Discussion Paper (28 July 1988) at 13.

17 Rob Merkin "The Christchurch Earthquakes Insurance and Reinsurance Issues" (2012) 18 Canta LR 119 at 121.

18 Iain Hay "Earthquake Insurance Reform in New Zealand" in Graham A Tobin and Burrell E Montz (eds) Evolving Approaches to Understanding Natural Hazards (Cambridge Scholars Publishing, 2015) 318 at 318.

19 Public Inquiry into the Earthquake Commission, above n 1, at 62.

20 Hay, above n 18, at 318.

21 At 318

22 New Zealand Government, above n 16, at 1.

23 At 1.

24 At 1.

25 Iain Hay "Neoliberalism and Criticisms of Earthquake Insurance Arrangements in New Zealand" (1996) 20(1) Disasters 34 at 36. 
to make their own decisions about insurance protection, ${ }^{26}$ the 1993 Act gradually removed cover for commercial property and motor vehicles. ${ }^{27}$

EQC's central policy framework is a social benefit delivered in a quasi-commercial way, aimed at community-wide disaster rather than individual misfortunes. ${ }^{28}$ EQC provides first-layer natural disaster insurance cover up to a $\$ 150,000$ (plus GST) cap for residential properties privately insured against fire. ${ }^{29}$ EQC provides cover to multi-unit dwellings by multiplying the number of dwellings in the building by $\$ 150,000 .{ }^{30}$ Homeowners pay for EQC cover through a compulsory levy on the private fire policy premium, ${ }^{31}$ although homeowners can voluntarily take out EQC cover without a fire policy. ${ }^{32}$ Above the cap, a second layer of cover applies under the insured party's private insurance policy. ${ }^{33}$ EQC cover applies to damage caused by an earthquake, natural landslip, volcanic eruption, hydrothermal activity or tsunami; a fire resulting from a natural disaster; or, in the case of only residential land damage, a storm or flood. ${ }^{34}$ Damage is defined as physical loss or property damage directly resulting from a natural disaster or measures taken to avoid the spreading of, or to otherwise mitigate, the consequences of a natural disaster. ${ }^{35}$ Levy proceeds are held in the Natural Disaster Fund, backed by private reinsurance. The fund's resources are finite, supported by a Crown guarantee to meet all liabilities in the event the Fund and reinsurance are exhausted. ${ }^{36}$ This guarantee was triggered for the first time in $2018 .^{37}$

26 Sally Priest and others Review of International Flood Insurance and Recovery Mechanisms: Implications for New Zealand and the Resilience of Older People (Flood Hazard Research Centre, Middlesex University, 2014) at 19.

27 Leicester Steven "The Earthquake \& War Damage Commission - A look forward (and a Look Back)" (1992) 25(1) Bulletin of the New Zealand National Society for Earthquake Engineering 52 at 54.

28 David Middleton Governments and the Consequences of Disaster (paper presented to 13th World Conference on Earthquake Engineering, Vancouver, August 2004).

29 Earthquake Commission Act 1993, s 18.

30 Section 18(1)(c).

31 Merkin, above n 17, at 123.

32 However, this option has minimal take up: See Earthquake Commission Act 1993, s 22.

33 Tamara Jenkin "When the Shaking Stops" [2018] 3 NZLJ 82 at 82.

34 Earthquake Commission Act 1993, s 2.

35 Section 2.

36 Section 16.

37 Earthquake Commission Annual Report 2018-2019 (November 2019) at 6. 


\section{B Reviewing New Zealand's Current Scheme}

Following the Canterbury earthquakes and subsequent events, it became readily apparent that New Zealand's current natural disaster insurance scheme contains many compelling features. Significantly, the compulsory attachment of EQC cover to fire insurance policies leads to near-universal application and places New Zealand within the highest uptakes of natural disaster insurance worldwide. ${ }^{38}$ The Government's ability to pool risks nationwide allows for the provision of affordable compensation even in high-risk places. This also drives high insurance uptakes. This high insurance penetration ensured the vast majority of affected homeowners were covered by insurance, reducing social hardships and leaving few families destitute. ${ }^{39}$ Further, it cushioned New Zealand from the fiscal impacts of the earthquakes, particularly given the closeness in timing to the Global Financial Crisis. ${ }^{40}$ Additionally, the certainty of a legislated right to natural disaster insurance with pre-established terms backed by a Crown guarantee meant homeowners did not have to rely on ad hoc assistance following these events. ${ }^{41}$

However, there are fundamental deficiencies in New Zealand's current system. The provision of public insurance itself poses serious moral hazard risks, the phenomenon whereby the existence of insurance alters individual's levels of risky behaviour. ${ }^{42}$ First, the EQC scheme imposes a uniform levy irrespective of property construction type or location. This does not reflect the fact that some regions are more vulnerable to certain natural disasters than others, nor the fact that different buildings are more prone to natural disaster damage. Problematically, those who go to the extra expense of seismically strengthening their property receive no levy deduction, hence diluting the incentives to adopt such precautions. ${ }^{43}$ Additionally, flat-rate premiums can encourage people to locate themselves in risky areas. In the United States (US) context, a White Paper study revealed the primary reason people moved into flood-prone areas was their anticipation of governmental flood protection. ${ }^{44}$ Presumably, the flat-rate EQC premiums similarly encourage more people to locate in disaster-prone

38 New Zealand Treasury New Zealand's Future Natural Disaster Insurance Scheme: Proposed Changes to the Earthquake Commission Act 1993 (July 2015) at 15.

39 Bryce Wilkinson and Eric Crampton Recipe for Disaster: Building Policy on Shaky Ground (The New Zealand Initiative, 2018) at 27.

40 Hugh Cowan, Bryan Dunne and Anna Griffiths "Planning for Loss or Complexity? New Zealand's Earthquake Commission: The Story So Far" (2016) 5 ConsorSeguros 1 at 13.

41 Cowan, Dunne and Griffiths, above n 40, at 4; New Zealand Treasury, above n 38, at 15.

42 George Priest "The Government, the Market, and the Problem of Catastrophic Loss" (1996) 12 J Risk Uncertain 219 at 227.

43 New Zealand Government, above n 16, at 2.

44 Howard Kunreuther "The Case for Comprehensive Disaster Insurance" (1968) 11(1) J Law Econ 133 at 134. 
areas than if they had to bear the loss themselves. ${ }^{45}$ In this sense, the EQC scheme means New Zealanders are not required to face the real risks of natural disasters. ${ }^{46}$

Secondly, as the scheme is not entirely universal, it does not eliminate the possibility that some homeowners choose not to insure in anticipation of government assistance. Since all homeowners are given the same opportunity to obtain EQC cover, the uninsured could simply be perceived as gamblers who lost: An attitude that exists concerning losses such as uninsured house fires. ${ }^{47}$ Following the Canterbury earthquakes this was generally the case; however, instances of government assistance for uninsured homeowners occurred in the "Red Zone". Although not legally obliged to intervene, there was significant political pressure for the Government to do so. ${ }^{48}$ This poses a moral hazard risk that others may choose not to insure, now aware that the Government will likely intervene. ${ }^{49}$

As a dual-insurance model, shortcomings in the private insurance market also have an impact on the overall workings of the scheme. Two serious problems have arisen following the Canterbury and Kaikōura earthquakes. Without system reform, grave issues will arise when the next major disaster strikes. First, after pressure from reinsurers, most residential insurers have shifted home insurance policies from 'full replacement cover' to 'sum-insured cover'. The insurer no longer rebuilds the home with a replacement of similar size and quality. Instead, the homeowner specifies an insurance value which represents a cap on the total amount the insurer will spend. ${ }^{50}$ While this move allows insurers to predict their overall liability more accurately, it effectively transfers risk assessment responsibility to homeowners; something evidence shows homeowners are either not willing or able to do accurately. ${ }^{51}$ Academic studies confirm individuals struggle to price risk posed by uncertain future events, explaining why homeowners are now purposely choosing to underinsure in fear of rising premiums. ${ }^{52}$ For instance, the Kaikōura earthquake revealed some homeowners had intentionally insured simply for the value of their mortgage, rather than the value of a home rebuild. ${ }^{53}$ Whether

45 Kunreuther, above n 44, at 135.

46 New Zealand Government, above n 16, at 2.

47 Kunreuther, above n 44, at 159.

48 Hon Dr Megan Woods "Government Announces New Red Zone Payment" The Beehive (21 August 2018)

49 Catherine Iorns Case Studies on Insurance and Compensation after Natural Disasters (Victoria University of Wellington Legal Research Paper for Deep South National Science Challenge, No 64, Wellington, 2018) at 20 .

50 Treasury Staff Insight 'Sum Insured' Cover for Household Insurance - What are the risks? (New Zealand Treasury, 9 May 2016).

51 James Beard, James Sergeant and Dillon Watts Home Insurance - Implications of Sum Insured Cover (Treasury Report T2015/1294, 23 June 2015) at 4.

52 At 13.

53 Stuff "Insurance in New Zealand is changing" (20 May 2019) <www.stuff.co.nz>. 
intentional or not, the move to sum-insured policies has left many underinsured with Treasury estimating up to 85 per cent of homes could now be underinsured by an average of 28 per cent. This presents an underinsurance figure of up to $\$ 184$ billion nationwide. ${ }^{54}$

While not all underinsured homeowners would experience shortfall following a disaster, widespread underinsurance poses a serious risk if many homeowners found themselves unable to rebuild. Not only does this increase adverse community recovery effects, it also increases the Government's potential fiscal responsibility. If this happened on a wide scale, there would likely be political pressure to provide financial support to affected homeowners. ${ }^{55}$ In contrast to the uninsured, it may be harder to resist demands for action in a sum-insured market, as arguably, people have done the right thing by obtaining insurance, ${ }^{56}$ but they are simply unable to claim sufficient restitution to regain their footing and rebuild. ${ }^{57}$ The anticipation of such support poses serious risks of homeowners further underinsuring, meaning the move to sum-insured policies exacerbates the moral hazard problems already rife in New Zealand's current system.

Secondly, there have been dramatic increases in private insurance premiums following insurers' adoption of risk-based premiums, especially in high-risk locations. ${ }^{58}$ For example, one Wellington resident reported a $\$ 5000$ annual increase, with Christchurch residents reporting increases of over $\$ 15,000, \$ 12,000$ and $\$ 5,000 .{ }^{59}$ While risk-based pricing means homeowners more accurately pay for their own risk, it imposes a danger of unaffordability. ${ }^{60}$ If homeowners are priced out of the private insurance market, this constitutes a danger of widespread underinsurance, especially in high-risk locations. This risk has already materialised. For example, some Wellington apartment body corporates have either significantly reduced or altogether abandoned natural disaster insurance in response to much higher premiums, ${ }^{61}$ despite this breaching the Unit Titles Act. ${ }^{62}$ If homeowners are extensively underinsured due to unaffordable private premiums, this increases both the community

54 Treasury Staff Insight, above $\mathrm{n} 50$.

55 Beard, Sergeant and Watts, above n 51, at 7 .

56 At 7 .

57 New Zealand Government, above n 16, at 1.

58 Tasmyn Parker "Wellington's rising insurance costs hurting businesses - but insider insists city's insurance market not broken" (10 June 2019) New Zealand Herald <www.nzherald.co.nz>.

59 Andrew Horne and Olivia de Pont "Risk under the microscope - a sea change in pricing property insurance" Cover to Cover (New Zealand, 2019) at 5.

60 Jenée Tibshraeny "IAG and Suncorp see premium hikes being more subdued in 2020, with major repricing seen in 2019 contributing to them increasing their profits by $69 \%$ and $116 \%$ respectively" Interest (20 August 2019) <www.interest.co.nz>.

61 Tibshraeny, above n 60 .

62 Unit Titles Act 2010, s 135: requires body corporates to keep all buildings insured to their full insurable value. 
impact of an event and the Government's fiscal responsibility if it is pressured to provide financial assistance to affected homeowners following a disaster.

\section{A NEW SCHEME?}

New Zealand's current scheme has clear benefits, but there are fundamental shortcomings. Moral hazard problems are many: By EQC premiums failing to distinguish between the relative riskiness of geographical areas and the burden of rigorous building standards, this dilutes incentives for individual risk mitigation and avoiding risky behaviour is reduced. ${ }^{63}$ Further, widespread underinsurance due to recent private insurance market adjustments and the scheme's non-universality increases the Government's political responsibility. As overseas experience demonstrates, governments feel compelled to provide financial assistance to affected households when there are large numbers of underinsured homeowners. ${ }^{64}$

Instead, New Zealand's system needs to strike a critical balance between assisting disaster victims adequately - providing the well-functioning ambulance at the bottom of the cliff - and ensuring people take precautionary measures, building their secure fence at the top. This balance recognises that while natural disasters are not the individual's fault, loss, to some degree, can be self-inflicted by choice of location and lack of preventative measures. ${ }^{65}$ The system also needs to support a well-functioning private insurance industry, minimise the Crown's fiscal risk for having to provide additional assistance after a disaster, and minimise the potential for homeowners to experience socially unacceptable distress and loss. ${ }^{66}$ With these objectives in mind, this article considers whether an entirely new approach would provide New Zealanders with a more effective scheme.

Three options are explored: a purely private scheme with no government involvement; a scheme with ex-post government involvement; and a scheme with ex-ante government involvement. Concluding that ex-ante involvement is the most beneficial, it is recommended that the Government maintain its role as a first-loss insurer.

\section{A Option One: No Government Involvement}

This is not a viable option: any effective system for New Zealand will require government involvement in some form. In an ideal world, the private insurance industry would take the responsibility of compensating natural disaster victims. Prudent homeowners would surely take out

63 New Zealand Government, above n 16, at 72 .

64 New Zealand Treasury, above n 38, at 15.

65 John McAneney and others "Government-sponsored Natural Disaster Insurance Pools: A view from downunder" (2016) 15 IJDRR 1 at 2.

66 New Zealand Treasury, above n 38, at 13. 
an insurance policy protecting them against natural disaster damage, and consequently, not require government assistance. However, as former EQC Chief Executive David Middleton has said: ${ }^{67}$

In practice, disaster after disaster ... has demonstrated that the [private] insurance mechanism does not work well for these events. Policies cost too much and are too restrictive. People choose not to purchase.

Additionally, natural disasters present unique challenges for the private insurance sector. Foremost, natural disasters are correlated risks, which refers to the simultaneous occurrence of many losses from a single event. ${ }^{68}$ Unlike an event such as an automotive accident, the likelihood that one policyholder will suffer natural disaster damage is not independent of the likelihood that another policyholder will suffer like damage. ${ }^{69}$ Because of this, a fully privatised natural disaster insurance scheme presents significant barriers as insurance companies are either unwilling to provide coverage for certain natural disasters or the premiums are such that they price many consumers out of the market. ${ }^{70}$ For instance, purely private hurricane, flood and earthquake insurance is either not available in disaster-prone areas of the United States or is extremely expensive. ${ }^{71}$ As governments can "dig deeper into their pockets", they are arguably better suited to handle correlated natural disaster risks. ${ }^{72}$ Further, as the absence of affordable property insurance threatens public health, safety and welfare, and likewise threatens the economic health of the state, the Government has a compelling interest in ensuring that property in New Zealand is insured at affordable rates. ${ }^{73}$ In contrast, private insurance companies are only in business to cover a risk where it is profitable to do so and are under no obligation to provide cover against increasingly uncertain risks. ${ }^{74}$ Therefore, because a fully privatised insurance market would either collapse for some forms of natural disaster insurance or would be unaffordable for everyday homeowners, some form of government involvement in New Zealand's natural disaster insurance scheme is required.

67 David Middleton "The Role of the New Zealand Earthquake Commission" (2001) AJEM 57 at 57.

68 World Finance "Correlated Risks" (30 June 2010) <www.worldfinance.com>.

69 N Scott Arnold "The Role of Government in Responding to Natural Catastrophes" (2000) 10 JEEH 1 at 15.

70 At 28.

71 Michael Trebilcock and Ronald Daniels "Rationales and Instruments for Government Intervention in Natural Disasters" in Ronald J Daniels, Donald F Kettl and Howard Kunreuther (eds) On Risk and Disaster: Lessons from Hurricane Katrina (University of Pennsylvania Press, Philadelphia, 2006) 89 at 93.

72 Arnold, above n 69, at 15.

73 Tristan Nguyen "Insurability of Catastrophe Risks and Government Participation in Insurance Solutions" (Paper Prepared for the Global Assessment Report on Disaster Risk Reduction 2013) at [2a].

74 Iorns, above n 49, at 10. 
Government involvement is also necessary in light of the Government's fundamental duty to house its citizens. ${ }^{75}$ This duty is reflected in many facets of New Zealand affairs. New Zealand has a history of state involvement in housing dating back to $1894,{ }^{76}$ and a key priority of the current Government is to break the cycle of homelessness. ${ }^{77}$ Following a natural disaster, this duty is of utmost importance as homelessness is of central concern. ${ }^{78}$ The Government's obligation to house its citizens is clearly implied through the purpose of the EQC scheme. ${ }^{79}$ For example, it was stated during the 1993 Act's debates that the Government's prime concern after a natural disaster is with the "provision of basic, adequate housing". ${ }^{80}$ This responsibility is reaffirmed in the Select Committee reports, ${ }^{81}$ and evident when analysing the removal of commercial property cover in 1993 - the rationale being an absence of an obligation to commercial property owners following a disaster. ${ }^{82}$ Further, in 2015, Treasury identified the scheme's core purpose as being "to ensure homeowners are able to put a roof over their heads after a natural disaster strikes." ${ }^{83}$ The obligation to intervene is further evident from New Zealand's human rights commitments. Following a natural disaster, human rights - in particular, the right to housing - are especially relevant. ${ }^{84}$ For example, art $25(1)$ of the Universal Declaration of Human Rights 1948 provides that: ${ }^{85}$

Everyone has the right to a standard of living adequate for the health and well-being of himself and of his family, including ... housing ... and the right to security in the event of ... lack of livelihood in circumstances beyond his control.

Evidently, human rights commitments necessitate government involvement in some form; this is an obligation the private sector does not have.

75 Middleton, above n 67, at 57.

76 Kainga Ora "History of State Housing" (13 November 2019) <kaingaora.govt.nz>.

77 New Zealand Labour "Extra Support to Tackle Homelessness" (26 February 2020) <www.labour.org.nz>; Cabinet Paper, above n 14, at [79].

78 Middleton, above n 67, at 57.

79 Public Inquiry into the Earthquake Commission, above n 1, at 62.

80 (15 December 1992) 532 ECB 583.

81 Disaster Advisory Group "Appendix 3: Summary of Submissions to earlier Discussion Document" (30 September 1988) in Disaster Insurance Policy: A White Paper (New Zealand Government, May 1989) at 3.1.2.

82 (15 December 1992) 532 ECB, above n 80; Middleton, above n 67, at 59.

83 New Zealand Treasury, above n 38, at 21.

84 Natalie Baird "Housing in Post-Quake Canterbury: Human Rights Fault Lines" (2017) 15 NZJPIL 195 at 197.

85 See similarly United Nations International Covenant on Economic, Social and Cultural Rights 14531 UNTS 993 (opened for signature 19 December 1966, entered into force 3 January 1976), art 11(1). 
Even without a public insurance scheme, political pressure following a natural disaster would necessitate government assistance in some form. With traditional state provider expectations, New Zealanders consistently look to the government of the day to assist and compensate those affected by significant events. ${ }^{86}$ This notion does not exclusively apply to natural disasters; in the tumultuous times that follow a societal disaster, the public regularly counts on the government to restore order. ${ }^{87}$ A simple analysis of the Covid-19 pandemic response shows firm expectations of government involvement to assist those affected. Even for individual misfortunes New Zealanders expect the Government to assist them, for example, through the government-subsidised public healthcare system and the Accident Compensation Corporation (ACC) scheme. Moreover, when establishing the EWDC in 1945, the Government assumed an explicit role in insurance arrangements to help New Zealanders in the aftermath of natural disasters. ${ }^{88}$ By doing so, the Government has imposed upon itself a practical obligation to intervene in future disasters in some form, even if the current public insurance scheme were to no longer exist. To fail to intervene following a natural disaster would threaten a general loss of confidence in the Government at a pivotal moment. ${ }^{89}$

Although government involvement is necessary, it is neither desirable nor viable to have no private market contribution. As New Zealand is a small country and economy, New Zealanders cannot expect an open-ended government commitment to pay the losses associated with natural disasters, whatever the cost or circumstances. ${ }^{90}$ Taxpayers cannot afford the burden if the Government were to keep taking on extra protections for people when there is a private insurance regime available. ${ }^{91}$ The maintenance of a hybrid public-private approach is to be preferred. The private insurance industry can play an important role in New Zealand's natural disaster insurance system, necessitating greater individual responsibility by doing what a private property regime does best: imposing the burdens of property ownership on those making decisions regarding that property. ${ }^{92}$ While a purely public scheme may face financial instability given political pressure to maintain affordable coverage in high-

86 D Quigley "The Role of the State as an Insurer of Last Resort?" (1990) 23 Bulletin of the New Zealand National Society for Earthquake Engineering 180 at 180.

87 Steven Sugarman "Roles of Government in Compensating Disaster Victims" (2007) Issues Leg Scholarsh 1 at 30 .

88 (15 December 1992) 532 ECB, above n 80.

89 Sugarman, above $\mathrm{n} 87$, at 30 .

90 Tim Grafton "Wellington: What's Really Happening Here?" (June 2019) CoverNote Live <covernote.co.nz>.

91 Radio New Zealand "Government should review quake insurance role - Wellington mayoral taskforce" (6 November 2019) <www.rnz.co.nz>.

92 Arnold, above n 69, at 29. 
risk areas, ${ }^{93}$ the Government's private counterparts can charge premiums appropriate to risk levels. ${ }^{94}$ Further, they can create innovative financial instruments to mitigate natural disaster risk, a task that may be more challenging for the public sector. ${ }^{95}$ Consequently, any approach adopted should include a collaborative public-private component.

\section{B Option Two: Ex-post Government Intervention}

The Government could remove itself from the provision of natural disaster insurance, instead providing victims with taxpayer-financed assistance after the event in combination with private insurance payouts. This approach is similar to that taken in societal disasters, such as the Covid-19 pandemic, and is used for natural disaster relief in Austria. ${ }^{96}$ However, it is not suitable for New Zealand's natural disaster insurance scheme. While a rationale for the ex-post approach is that, out of solidarity, public funds should be used to provide compensation, the approach poses moral hazard risks far more dangerous than those in the current scheme. ${ }^{97}$ The availability of this "free form of insurance" would encourage risk-taking by individuals and dilute the incentives to purchase insurance, ${ }^{98}$ resulting in extensive underinsurance. ${ }^{99}$ As one scholar noted, "'solidarity kills market insurance'". 100 With the insured and uninsured receiving the same compensation, the gambler would be rewarded at the expense of the prudent or cautious individual. ${ }^{101}$

Unlike homeowner's current contributions through EQC premiums, the approach would leave the Government and taxpayers exposed to significant unfunded fiscal risks. ${ }^{102}$ Although supporters of this approach argue that it may encourage the Government to take cost-benefit justified precautions before a disaster, ${ }^{103}$ realistically, the Government is unlikely to engage in these intensive saving regimes. Cutting investment elsewhere to save for an unpredictable future event is unlikely to garner

93 McAneney, above n 65, at 1.

94 Priest, above n 42, at 228.

95 Jeff Dayton-Johnson Natural Disasters and Adaptive Capacity (OECD Development Centre Working Paper No. 237, France, 2004) at 28.

96 Véronique Bruggeman, Michael Faure and Tobias Heldt "Insurance against catastrophe: Government Stimulation of Insurance Markets for Catastrophic Events" (2012) 23 Duke Envtl L \& Pol'y F 185 at 191.

97 At 190 .

98 Kunreuther, above n 44, at 139.

99 New Zealand Treasury, above n 38, at 8 .

100 Véronique Bruggeman, Michael Faure and Karine Fiore "The Government as Reinsurer of Catastrophe Risks?" (2010) 35 The Geneva Papers 369 at 371.

101 Kunreuther, above n 44, at 139.

102 New Zealand Treasury, above n 38, at 15.

103 Bruggeman, Faure and Heldt, above n 96, at 205. 
much political support. ${ }^{104}$ Evidently, this approach is not suitable for New Zealand. It is contrary to the objectives proposed by this article and poses fundamental moral hazard risks far more significant than the current scheme does.

\section{Option Three: Ex-ante Government Intervention}

Ex-ante government intervention is, therefore, necessary. There are two potential forms this could take: The Government could reduce its capacity to provide reinsurance for high-end losses; or it could continue to act as a first-loss insurer. The reinsurance approach has credibility. For example, the Japanese Government requires private insurers to offer earthquake coverage but provides reinsurance to a total payment limit per event. ${ }^{105}$ Further, the Council of Australian Governments in 2011 recommended Australia adopt this approach in the context of flood insurance. ${ }^{106}$

Beneficially, the Government's size and sovereign rating would enable it to provide reinsurance at a cheaper rate than most private insurers. ${ }^{107}$ For example, the Florida Hurricane Catastrophe Fund can supply reinsurance at a 40 per cent lower cost than the global reinsurance market. ${ }^{108}$ If private insurance companies were able to obtain cheaper reinsurance and lower their risk of insolvency (if the Crown guarantee was retained), this would lower private premiums. ${ }^{109}$ This approach also helps balance government and individual responsibility. Without the provision of flat-rate EQC premiums, the premium would be paid by the homeowners who actually run the risk of damage. ${ }^{110}$ Further, the model's simplicity of design would allow New Zealanders to escape from the current quagmire that is the dual-insurance model. ${ }^{111}$ Interactions between parties were a source of immense friction following the Canterbury earthquakes. Yet, if EQC were simply a reinsurer, claims would fall to the private sector only. Additionally, this approach may lead to a more efficient recovery. For instance, 99.5 per cent of Japanese claims arising from the March 2011 earthquake and tsunami were settled with

104 Trebilcock and Daniels, above n 71, at 98.

105 Charlotte Kirschner and Marvin Phaup "Budgeting for Disasters: Focusing on the Good Times" (2010) 1 OECD Journal on Budgeting 1 at 15.

106 David Middleton Insurance Shocks: Market Behaviour and Government Responses (Kestrel Group, Wellington, 2012) at 4.

107 Michael Naylor "Opinion: EQC Review Not Bold Enough" (10 July 2015) Massey University <www.massey.ac.nz>.

108 David Middleton "Submission to Treasury on the Earthquake Commission (EQC) Act Review 2015" at 10.

109 Kunreuther, above n 44, at 151.

110 Bruggeman, Faure and Fiore, above n 100, at 375

111 Naylor, above n 107. 
fourteen months of the event, ${ }^{112}$ despite generating nearly 900,000 residential claims. ${ }^{113}$ Thus, this approach could assist in reducing the distress and delays currently associated with natural disasters.

Prima facie, this approach is an attractive option. However, in many ways, it risks worsening, rather than alleviating, the deficiencies in New Zealand's current scheme. ${ }^{114}$ As established, even the current involvement of the private insurance market as providers of "top-up" cover is hugely problematic. Implementing complete reliance on the private market for first-loss cover would undeniably aggravate these issues. While private insurance premiums would be lowered to some extent under this approach, it is doubtful whether they would be able to provide the same level of extensive, affordable cover that EQC does. Additionally, without requirements that require provision for coverage for certain hazards, this may cause insurers to withdraw from the market altogether. This imposes grave dangers that high-risk homeowners may not be able to access insurance at all or do so only at prohibitively expensive rates. ${ }^{115}$ Further, it is well known that people do not voluntarily undertake insurance. Unless a requirement for homeowners to obtain cover was implemented, one returns to the exact reason why the EWDC was created in the first place.

The unsuitability of this approach compared to New Zealand's current scheme is evident when analysing the impacts of the Canterbury earthquakes under this method. For example, despite the average loss amounting to 10 per cent of the home's value, Canterbury homeowners would have received merely five per cent of their insured amount under the Japanese scheme. Homeowners would have received just over $\$ 9,000$ each, an amount significantly lower than the $\$ 40,000$ average that was paid by EQC alone. Additionally, only 30 per cent of homeowners would have been insured against earthquake damage. ${ }^{116}$ In conclusion, adopting this alternative approach is not sensible. It would only increase the problems of underinsurance and impose a greater risk of political pressure for Government compensation, subsequently worsening the degree of moral hazard.

This reveals that the shape of New Zealand's scheme is broadly right, despite the many areas for improvements. Reducing the Government's role to a reinsurance capacity would likely exacerbate the current issues and bring new problems of its own, effectively intensifying the impacts of natural disasters. As New Zealand's approach has been termed the "envy of the world", ${ }^{117}$ it would be foolish

112 Finn and Toomey, above n 3, at 221.

113 Marsh Comparing Claims from Catastrophic Earthquakes (Marsh Risk Management Research, February 2014) at 2.

114 Finn and Toomey, above n 3, at 225.

115 At 226

116 Cuong Nhu Nguyen and Ilan Noy "Comparing Earthquake Insurance Programmes: how would Japan and California have fared after the 2010-11 Earthquakes in New Zealand" 44(2) Disasters 367 at 374.

117 Insurance Council of New Zealand "Submission to Treasury on the Earthquake Commission (EQC) Act Review 2015". 
to embark on a new approach when New Zealand already has an admirable system. It simply needs improving. Consequently, it is proposed that the dual-model approach be retained with first-loss cover falling to EQC as this has the greatest potential to meet the identified objectives and provide New Zealanders with the effective system they deserve.

\section{RECOMMENDATIONS FOR REFORM}

While concluding that the overall shape of the current scheme is to be maintained, it is clear that substantial reforms are required in light of the scheme's current deficiencies. Five reforms are proposed: Ensure the scheme's universality; increase the EQC cap; implement differentiated pricing; incorporate incentives for mitigation; and include a purpose statement in the Act.

\section{A Universality}

The scheme should be utilised by all New Zealand homeowners and needs to be administered in a way that ensures it is. This article proposes introducing a combination approach to levy collection through the current attachment to private fire insurance policies and direct EQC billing to those who do not have fire insurance. ${ }^{118}$ Indeed, a fully universal EQC scheme would extend EQC's fiscal responsibility as it now insures every residential homeowner, albeit with contribution from the homeowners themselves. However, this is offset by eliminating the risk of taxpayer-funded assistance for uninsured homeowners after the event and would remove the moral hazard risk of homeowners purposely not insuring in anticipation of this assistance.

\section{$B$ Increasing the EQC Cap}

The EQC cap should be increased to $\$ 400,000$. The initial cap of $\$ 100,000$ was introduced in 1993 to reflect the cost of rebuilding a New Zealand modal-value home following a natural disaster. ${ }^{119}$ It was believed this sum would "do away with any need for top-up insurance cover". ${ }^{120}$ However, due to inflation, this sum is outdated; the average cost of building a residential property now being closer to $\$ 400,000 .{ }^{121}$ Although the cap was increased to $\$ 150,000$ in 2019 , this sum is still inadequate to enable the average homeowner to rebuild. ${ }^{122}$ Dame Cartwright considered a review of the cap is "essential" and similarly recommended that the cap increase to cover the average cost of building a house. ${ }^{123}$ Likewise, the 2019 Mayor's Insurance Taskforce in Wellington considered raising the cap

118 New Zealand Government Disaster Insurance Policy: A White Paper (May 1989).

119 Wellington City Council Mayor's Insurance Taskforce: Discussion Document (November 2019) at 13.

120 (15 December 1992) 532 ECB 583, above n 80.

121 Public Inquiry into the Earthquake Commission, above n 1, at 64.

122 At 21.

123 At 21. 
to $\$ 400,000$ as an "obvious step to contemplate", ${ }^{124}$ with Middleton agreeing "it needs to be $\$ 400,000$ now". ${ }^{125}$ Cabinet has indicated that lifting the cap will be considered during the 2021 review. ${ }^{126}$

In addition to meeting the initial purpose of the cap, an increase to $\$ 400,000$ would bring many other improvements to New Zealand's scheme. First, with only a slight adjustment of the cap since 1993, the value of the cap in real terms i.e., adjusted for inflation, has reduced substantially. As homeowner's reliance on "top-up cover" has increased, EQC is now carrying less of the total residential building exposure while private insurers are carrying more. ${ }^{127}$ Given that recent shifts in the private insurance market have left many homeowners underinsured, this increased reliance on the private insurance market is problematic. The Wellington Mayor's Insurance Taskforce stated that as the purpose of EQC was to "sustain a viable insurance market and reduce the volatility of pricing for natural disasters,"128 increasing the cap is necessary to maintain natural disaster insurance affordability. This reform may also lower private premiums by shifting the balance of EQC and private insurers' risk exposure (although, the increase in EQC premiums may offset this). ${ }^{129}$ Additionally, by reducing the level of underinsurance, the likelihood of unfunded government assistance reduces. In this sense, this reform proposed reduces the Government's potential responsibility and limits the moral hazard problems that currently exist.

As the Natural Disaster Fund has been depleted, it is important to implement changes that ensure calling on the Crown guarantee is the last resort, not the default. This reform would expand the resources available to EQC by raising premiums. Without being accurately adjusted for inflation, the cap has reduced EQC's premium income far more than lessening its liability. ${ }^{130}$ However, with premium growth exceeding EQC's liability growth, the higher the cap, the faster the fund will grow. ${ }^{131}$ EQC's liability seemingly dramatically increases with a $\$ 400,000$ cap. Yet, with the bulk of the liability incurred at the lower caps, the risk of the scheme increases by far less than the monetary increase suggests. ${ }^{132}$ This is because the probability of claims between $\$ 150,000$ and $\$ 400,000$ is

124 Public Inquiry into the Earthquake Commission, above n 1, at 50.

125 Sam Farrell "Former head of Earthquake Commission says EQC cap should be increased to \$400,000" (10 June 2019) Newshub <www.newshub.co.nz/>.

126 Cabinet paper, above n 14, at 17.

127 New Zealand Treasury, above n 38, at 24.

128 Wellington City Council, above n 119, at 13.

129 Public Inquiry into the Earthquake Commission, above n 1, at 64

130 Earthquake Commission Briefing to the Incoming Minister (December 2011) at 32.

131 Middleton, above n 108, at 7.

132 Cabinet Economic Growth and Infrastructure Committee Paper "Release of Discussion Document: Legislative Review of the Earthquake Commission Act 1993" (24 June 2015) (obtained under Official Information Act 1982 Request to the Financial Markets Group, New Zealand Treasury) at 9. 
much lower than that of claims up to $\$ 150,000 .{ }^{133}$ Further, any increase in EQC's liability is balanced by its decreased liability after removing personal property cover in $2019,{ }^{134}$ and reducing the Government's risk of providing unfunded assistance. This reform would also reduce the level of homeowner distress following a natural disaster by substantially reducing the number of over-cap claims, an area of major friction and uncertainty following the Canterbury Sequence. ${ }^{135}$ As the $\$ 100,000$ cap proved inadequate for the repair of many properties, there was far greater interaction than desirable between EQC and private insurers, resulting in delays to recovery. ${ }^{136}$ Overall, it would achieve a more optimal split between EQC and private insurance cover. ${ }^{137}$

The cap increase should be complemented by a requirement to review the cap at least every five years. Any significant change in the real value of EQC cover needs to be a deliberate policy choice, rather than changes resulting from not matching inflation. ${ }^{138}$ Although an automatic adjustment mechanism was suggested in $2011,{ }^{139}$ this was decided against in $2015 .{ }^{140}$ Because judging the appropriate cap is not a simple technical exercise but requires judgment about insurance market conditions and the Government's role in making good private losses, a formal policy review is most suitable. Further, as the real value of cover is unlikely to erode quickly within a low inflation environment, the default five-year review ensures the policy intent is reflected. ${ }^{141}$ However, further changes to the cap in these reviews should be made only when they are material and based on sufficient need, for example, if the cap no longer meets the original policy intent. This recognises the significant impacts of changing the cap, such as the time intensive and expensive processes of changing systems, processes, policy terms and wordings. ${ }^{142}$

The cap increase should be complemented by a provision that the cap does not reinstate after each event. Currently, as EQC cover reinstates to 100 per cent after each event, EQC is liable for payment of its $\$ 150,000$ cap value for damage incurred by each separate event. ${ }^{143}$ Under this approach,

133 Middleton, above n 108, at 8.

134 Before the 2019 amendment to the Act, coverage for personal property was also provided for up to $\$ 20,000$; See Merkin, above n 17, at 122 .

135 New Zealand Treasury, above n 38, at 11.

136 Public Inquiry into the Earthquake Commission, above n 1, at 21.

137 Earthquake Commission, above n 130, at 5.

138 New Zealand Treasury, above n 38, at 32.

139 Earthquake Commission, above n 130, at 5.

140 New Zealand Treasury, above n 38, at 32.

141 At 32 .

142 Vero Insurance "Submission to Treasury on the Earthquake Commission (EQC) Act Review 2015" at 15.

143 Re Earthquake Commission HC Wellington CIV-2011-485-1137 2 September 2011, [2011] BCL 695. 
claimants can receive cover for which they have not paid. For example, if a homeowner insured their property for $\$ 151,000$, and there were three events within a policy year causing $\$ 150,000$ damage each, this could result in a $\$ 450,000$ rebuild from EQC cover alone, despite the homeowner only paying one EQC premium during that time. Insurers who have collected premiums over and above the EQC cap should also be expected to contribute when repair costs go over-cap, something that may not happen in this scenario. ${ }^{144}$ While the current reinstatement policy potentially reduces the level of underinsurance, it increases the Government's fiscal responsibility. It also increases moral hazard risks that homeowners may not insure past the EQC cap on the basis that it will reinstate after each event.

Reinstatement could be approached in three potential ways. First, reinstatement could occur after the policy year has concluded, irrespective of the number of events occurring during that year. This is proportional to the yearly EQC premium paid by homeowners and would reduce the Government's fiscal responsibility. However, this does not serve to remedy the complexities of damage apportionment issues which caused much stress and delays after the Canterbury earthquakes. If two events were to occur in a timely manner, but on either side of the policy year, these issues would be common. The second option is for the cap to reinstate after a cluster of events. However, this is difficult to implement given the unpredictable nature of natural disasters. It may result in delays to recovery, as private insurers would have to wait until the unknown date the cluster was finished before they began to repair over-cap claims. Therefore, the third option is the most preferrable. Suggested by the Insurance Council of New Zealand, the cap could reinstate after repairs are finished. ${ }^{145}$ This would reduce the complexities of damage apportionment and would provide certainty to homeowners. It also encourages repairs to be undertaken as quickly as possible, thus, providing more efficient recovery for affected communities. ${ }^{146}$

\section{Differentiated Pricing}

Section 36(1)(c) of the EQC Act allows but does not require differentiated premium pricing. One option would be to replace the current nationwide flat-rate levy with risk-based premiums. This would require homeowners to face the real risk of natural disasters. As homeowners would likely make choices to lower that risk, such as strengthening their homes or locating in less risky areas, ${ }^{147}$ this incorporates a higher degree of individual responsibility within the scheme. The location of fewer people and fewer poorly built structures in disaster-prone areas may also limit homeowner distress and loss following a disaster. ${ }^{148}$ Risk-based premiums would also ensure that the scheme is

144 Insurance Council of New Zealand, above n 117, at 16.

145 Vero Insurance, above n 142, at 10.

146 Insurance Council of New Zealand, above n 117.

147 Iorns, above n 49 , at 20 .

148 New Zealand Government, above n 16, at 19. 
economically efficient, which minimises the Government's fiscal risk and provides confidence that the scheme will endure. ${ }^{149}$

While they have compelling features, other attributes of risk-based premiums would instead defeat the objectives of this article. Consequently, their implementation is not recommended. First, a public insurance regime like EQC cannot guarantee access to insurance on equitable terms, whilst being risksensitive. ${ }^{150}$ Risk-based premiums would significantly increase EQC premiums in the parts of New Zealand already impacted by the private sector's move to risk-based pricing. ${ }^{151}$ This imposes a danger that both public and private insurance cover becomes unaffordable for these homeowners. As this would lead to widespread underinsurance in high-risk locations and increase the potential pressure for government assistance, it perpetuates the problem that is to be remedied. ${ }^{152}$ Secondly, natural disaster risks are difficult to quantify, resulting in administrative difficulties and the possibility of arbitrary criteria when setting these rates. ${ }^{153}$ To emphasise, as Canterbury was considered low risk in terms of earthquake damage, hypothetically, Christchurch homeowners would have paid merely a quarter of the premium of Wellington homeowners, despite nearly exhausting the Natural Disaster Fund. ${ }^{154}$ If a seemingly "low-risk" area were to make a large EQC claim, despite contributing less than other areas, risk-based premiums would be seen as unfair. ${ }^{155}$

One potential solution could be to impose a flat-rate premium for quantifiably difficult risks, such as earthquakes, but implement risk-based premiums for other risks such as volcano and flood where some locations have little to no risk of damage from these events. However, the implementation of this approach would be fraught with difficulty, especially if EQC were to be universal as this article suggests. The differences between homes, and the types of risks they cover, would likely be a controversial matter. This type of controversy is exemplified by ACC's difficulty with motor vehicle registration based on car safety ratings. ${ }^{156}$

Risk-based premiums are a tool that can help strike the balance between individual and government responsibility, but any attempt to implement them in practice would be politically

149 New Zealand Treasury, above n 38, at 40.

150 John O'Neill and Martin O'Neill Social Justice and the Future of Flood Insurance (Joseph Rowntree Foundation, 2012) at 6.

151 New Zealand Treasury, above n 38, at 42.

152 At 42 .

153 Letter from RB Chapman (Secretary to the Treasury) to Chair of the Finance and Expenditure Committee regarding the Earthquake Commission Bill 1993 (27 April 1993) at [56].

154 Iorns, above n 49, at 21.

155 New Zealand Treasury, above n 38, at 42.

156 Middleton, above n 108, at 15. 
difficult. ${ }^{157}$ It is crucial to remember the public context of the EQC scheme. A state-sponsored social insurance scheme should not mirror the strict allocation of risk as seen in the private sector; to do so would defeat the purpose of the public scheme. ${ }^{158}$ The EQC scheme should instead focus on maintaining high insurance penetration, especially in light of the current issues in the private insurance market. ${ }^{159}$ This necessitates retaining risk-insensitive premiums, although, the Act should retain the legislative flexibility to implement these if desired. ${ }^{160}$

Instead, the ability to incorporate differentiated pricing should be used to implement value-based pricing. The current flat-rate pricing is regressive in nature and results in lesser value homes subsiding those of higher value. ${ }^{161}$ For example, a home worth $\$ 500,000$ would need to sustain 30 per cent of damage to obtain the current $\$ 150,000$ EQC maximum payout. Whereas a home worth $\$ 250,000$ would have to sustain 60 per cent of damage, a far less likely occurrence despite both homes paying the same premium. ${ }^{162}$ While EQC's flat-rate premiums aim to provide an equitable scheme, they effectively transfer risk from the rich to poor. These issues would be compounded if the cap were lifted to $\$ 400,000$, as suggested in this article. Shifting from flat-rate premiums to premiums set on the total sum-insured value would remedy this regressive effect. It would reflect the likelihood that higher sum-insured homes are more likely to claim larger amounts under the EQC scheme. While EQC premiums would increase for the high-value homes, they would remain affordable. ${ }^{163}$

\section{Mitigation Incentives}

Mitigation has been termed "the starting point for managing the impact of natural catastrophes". ${ }^{164}$ Although mitigation measures cannot eliminate natural disasters, they can help property owners and communities become more resilient to damage and less susceptible to losses. ${ }^{165}$ However, the EQC system currently lacks any means of encouraging these measures. Flat-rate premiums, while ensuring the availability of affordable insurance, discourage homeowners from

157 McAneney, above n 65, at 6.

158 Iorns, above n 49, at 21.

159 Cabinet Economic Growth and Infrastructure Committee, above n 132, at 8.

160 At 12 .

161 Sally Owen and Ilan Noy "Regressivity in Public Natural Hazard Insurance: A Quantitative Analysis of the New Zealand Case" (2019) 3 Economics of Disasters and Climate Change 235 at 253.

162 Middleton, above n 108, at 7.

163 Owen and Noy, above n 161, at 253.

164 Federal Insurance Office, US Department of the Treasury Report Providing an Assessment of the Current State of the Market for Natural Catastrophe Insurance in the United States (September 2015) at 49.

165 At 49. 
undertaking the additional expenses of ensuring their home is less vulnerable to damage. ${ }^{166}$ Just as the introduction of welfare had the consequence of encouraging undesirable patterns of behaviour, EQC's public insurance scheme encourages undesirable behaviours in the face of natural disaster risks, including the ignorance of mitigation measures. ${ }^{167}$ Arguably, the security of having a safer house and being less susceptible to damage following a natural disaster would be an incentive to undertake these measures. In reality, voluntary implementation of these measures is minimal due to many of the same factors that result in low take up of voluntary insurance: Low awareness, affordability concerns and expectation of government assistance. ${ }^{168}$ Accordingly, it is proposed that incentives for mitigation within the EQC scheme be introduced, a reform also proposed by the Wellington Mayor's Insurance Taskforce. ${ }^{169}$

While EQC has no direct responsibility for mitigation, mitigation has a legitimate place within the scheme. Part of EQC's role is research and education; ensuring New Zealanders are aware of home safety and mitigation measures. ${ }^{170}$ This is important as many homeowners perceive insurance as the only means of dealing with natural disaster risks, despite insurance itself not being able to improve a building's resilience. ${ }^{171}$ Therefore, EQC already plays an important mitigation role by helping property owners become aware of certain mitigation strategies. This role needs to go further: Incentives for homeowners to undertake these measures need to be explicitly included within the scheme.

There are many options for implementing these incentives within New Zealand's scheme. Engaging in cost/benefit analyses and delving into the intricate workings of each approach is outside of the scope of this article. However, it is recommended that EQC utilises excesses to incentivise property owners to take cost-effective measures to safeguard their properties. This was a reform suggested by EQC itself. ${ }^{172}$ While an excess aims to keep overall premiums costs down by enabling homeowners to retain some of the risk, ${ }^{173}$ EQC should reward prudent homeowners who undertake

166 Eugene Gurenko and others Earthquake Insurance in Turkey: History of the Turkish Catastrophe Insurance Pool (The World Bank, Washington, 2006) at 105.

167 Arnold, above n 69, at 30

168 Organisation for Economic Cooperation and Development [OECD] Financial Management of Earthquake Risk (2018) at 18.

169 Kate Nicol-Williams "Sweeping changes proposed to help curb Wellington's skyrocketing insurance premiums" (8 October 2019) TVNZ <www.tvnz.co.nz>

170 Public Inquiry into the Earthquake Commission, above n 1, at 67.

171 T Egbelakin and K Mills Challenges in Managing Residential Earthquake Insurance: A Post-Disaster Review (Massey Research Online, 2016).

172 Earthquake Commission, above n 130, at 32.

173 At 32 . 
certain mitigation measures with excess reductions. The reward for the adoption of risk-reduction measures under this approach - a lower excess fee in the case of future potential loss - may be perceived as too distant or uncertain by the policyholder, ${ }^{174}$ but risk-based excesses are preferable to risk-based premiums as they maintain the affordability of insurance.

This approach will need to be implemented alongside a general excess increase. Providing a subsidy on the already low excess amount is neither viable nor consistent with the scheme's purpose of rehousing homeowners which is aimed at community-wide disaster, rather than individual misfortunes. ${ }^{175}$ Subsidising the already low excess levels would risk EQC paying out for minor damage. While distressing for the claimant, this type of damage is hardly an event of national concern, the exact reason why the Government provides public insurance for natural disasters but not individual losses like house fires. ${ }^{176}$ Therefore, if the scheme were to include mitigation incentives through excess subsidies, it would need to be done in conjunction will a general excess increase.

Another option is for the Government to provide grants or loans for implementing mitigation measures. This approach has been successfully implemented in the US context. For example, the California Residential Mitigation Program provides grants for homeowners to retrofit their properties to better withstand earthquakes, ${ }^{177}$ and the Federal Emergency Management Agency offers grants to assist individuals in mitigating risks associated with flooding. ${ }^{178}$ This approach could be implemented alongside excess reductions.

Introducing this reform would meet many of the objectives set out in the article for creating an effective scheme. First, it would reduce unacceptable loss and distress to homeowners following a natural disaster as implementing mitigation measures results in fewer losses and safer, more resilient communities. ${ }^{179}$ It would also reduce the fiscal impacts of natural disasters. For example, in the US context, a 2005 study found that "a dollar spent on hazard mitigation provides the nation about $\$ 4$ in future benefits." ${ }^{180}$ This reform may also have a positive impact of private insurance affordability. ${ }^{181}$

174 Alberto Monti "Policy Framework for the Improvement of Financial Management Strategies to Cope with Large-Scale Catastrophes in Chile" (High-Level Roundtable on the Financial Management of Earthquakes, OECD Headquarters, Paris, 23-24 June 2011) at 29.

175 Middleton, above n 28.

176 Middleton, above n 28.

177 GovTrack "HR 2053: Earthquake Mitigation Incentive and Tax Parity Act of 2019" (15 April 2019) www.govtrack.us

178 Federal Insurance Office, above n 164, at 52.

179 At 50 .

180 At 50.

181 Xijun Yao and others "Public-Private Partnership for Earthquake Mitigation Involving Retrofit and Insurance" (2017) 23 Technol Econ Dev Econ 810 at 812. 
As the Treasury identified, government support for risk reduction and mitigation could help ease the current insurance pricing and availability pressures as it mitigates the underlying risks. ${ }^{182} \mathrm{An}$ aggregate reduction in premium levels would then follow. ${ }^{183}$ There is a chance however, that on an individual homeowner level, undertaking these measures would lead to higher premiums. As these measures would increase the home's value, there would be a higher sum-insured value. To avoid this, the Government may need to assist with premium subsidies for affected homeowners in order to continue to incentivise undertaking these measures.

This reform would also meet the objective of effectively providing compensation for financial losses in the case of a disaster while also encouraging individuals to implement preventative measures to reduce their overall loss. ${ }^{184}$ In this sense, it meets the balance of providing the well-functioning ambulance at the bottom of the cliff, while encouraging individuals to build their secure fence at the top. While the Government is likely to always be compassionate in its approach to compensating disaster victims, it would be irresponsible for the Government not to take precautions wherever possible to minimise the cost and pain of natural disasters. ${ }^{185}$ This includes encouraging citizens to undertake mitigation measures themselves through implementing this reform.

\section{E Purpose Statement}

The EQC Act lacks a clear purpose statement. In 2015, Treasury proposed a purpose statement to be added but this amendment did not proceed. Dame Cartwright recommended the Government include a purpose statement to guide the discharge of EQC's responsibilities as an insurer with social responsibilities to its claimants. ${ }^{186}$ A purpose statement is needed to clarify EQC's role and signal to New Zealanders what to expect from New Zealand's natural disaster insurance scheme. ${ }^{187}$

In addition to assisting judicial interpretation, this proposal meets many of this article's objectives. First, explicitly articulating EQC's social responsibility to rehouse natural disaster victims would lead to less unacceptable distress following an event as this obligation would be at the core of EQC's decision-making. After the Canterbury earthquakes, it was widely believed that EQC lost sight of this

182 Cabinet Paper "Property Insurance Markets: Update and Next Steps Information Release" (7 August 2019) CABDEV-19-SUB-0208.

183 Middleton, above n 106, at 2.

184 Nguyen, above n 73, at 4 .

185 New Zealand Government, above n 16, at 2.

186 Public Inquiry into the Earthquake Commission, above n 1, at 26.

187 At 63. 
fundamental purpose and consequently placed insufficient emphasis on community recovery and resilience. ${ }^{188}$

Secondly, if EQC's core purpose of settling residential insurance claims was outlined, EQC would not be conferred additional responsibilities inconsistent with this purpose. ${ }^{189}$ As Dame Cartwright stated, the issues associated with EQC's additional functions post-Canterbury may have been avoided if EQC's functions, purpose and desired outcomes had been clarified. ${ }^{190}$ There would thus be more efficient recovery.

Thirdly, if a homeowner's individual responsibility to manage some of their own risk was articulated, this would improve the understanding that individuals do need to build their secure fence at the top of the cliff, and that they cannot solely rely on EQC to rescue them. Many Canterbury homeowners felt abandoned by EQC, a feeling exacerbated by high expectations of EQC support stemming from a misunderstanding of EQC's public purpose. Many homeowners believed EQC was a body endorsed by the Government that would step up and save the day following a natural disaster. ${ }^{191}$ If a purpose statement articulated both EQC's core purpose and an individual homeowner's responsibility to manage some of the risk themselves, this may help avoid this misunderstanding.

There should be implementation of the purpose statement proposed by Treasury in $2015,{ }^{192}$ but with additions that better reflect the objectives set out in this article. The purpose statement should read:

To establish a Crown-owned natural disaster insurance scheme for all residential buildings in New Zealand that:

- $\quad$ has affected homeowners at the forefront of decision-making and an emphasis on community recovery following a natural disaster;

- supports, complements and is closely coordinated with the provision of effective and accessible private insurance services to the owners of residential buildings;

- recognises the importance of housing in supporting the recovery of communities after a natural disaster and subsequently supports fast and effective repairs;

- $\quad$ supports improved resilience of New Zealand communities and an efficient approach to the overall management of natural hazard risk and recovery in New Zealand by incorporating a degree of individual homeowner responsibility in managing their risk;

188 Public Inquiry into the Earthquake Commission, above n 1, at 63.

189 Cabinet Paper, above n 14, at 17.

190 Public Inquiry into the Earthquake Commission, above n 1, at 69.

191 At 101 .

192 New Zealand Treasury, above n 38, at 19. 
- $\quad$ contributes to the effective management by the Crown of fiscal risks associated with natural disasters by financially preparing in advance of an event.

\section{CONCLUSION}

New Zealanders expect and deserve an effective natural disaster insurance scheme that has their best interests in mind. This scheme also needs to meet a crucial balance between individual and government responsibility, limit the possibility for unfunded government assistance after an event and ensure that all New Zealanders are protected against unacceptable loss and distress following an event. New Zealand's current scheme fails to meet this standard. Following the March 2020 Public Inquiry report and in anticipation of Treasury's 2021 review of the EQC Act, this article has determined the most effective natural disaster system for New Zealanders. In the light of identified deficiencies, the proposals are to reform the current system. Concluding that the dual-model approach is to be retained, five reforms are proposed for incorporation within the scheme: ensuring the scheme's universality; increasing the EQC cap; implementing differentiated pricing; incorporating incentives for mitigation; and including a purpose statement within the Act. Implementing these reforms will best provide New Zealanders with an effective scheme that protects them after a natural disaster strikes. 